\title{
8
}

\section{THE ARCHAEOLOGY OF THE WALKMAN}

\section{Audience perspectives and the roots of mobile media intimacy}

\author{
Maruša Pušnik
}

When du Gay et al. (2013/1997) made a cultural study of a material device, the Sony Walkman, ${ }^{1}$ in the late 1990 s, with clear observations about the symbolic meanings of culture, nobody realized that it would become the most famous book in its field. Moreover, at the time, nobody realized that the Walkman already predicted a dramatic extension of the era of media that had first been identified as 'mobile privatization' by Raymond Williams in 1974. Therefore, present concerns must be projected precisely onto that past to understand the rise of mobile and privatized, intimate, online mediatized worlds. In their preface to the 2013 edition of Doing Cultural Studies: The Story of the Sony Walkman, the editors write that while the media landscape has changed greatly since it was first published, the book's analysis of the material cultural artefact that was the Walkman can help us critically reflect the past

in relation to examining the practices attached to the mobile devices we use now; in other words, their place in how we live now, and just how new and different that 'now' is (or is not) from the 'now' of the Walkman.

(du Gay et al. 2013/1997, xiv)

Most studies of the Walkman have concentrated on the producers or marketers; however, my intention in this chapter is to emphasize the mass users of the Walkman. To understand the social construction of the Walkman, it is crucial to include its consumers in the analysis. ${ }^{2}$ This chapter investigates the archaeology of a portable media player, the Walkman, and its development from a portable audio cassette player to the Discman, from the perspective of audiences real users of portable entertainment devices. The Walkman boomed all over the world in the 1980s and represents the beginnings of mobile intimacy. My intention is to seek the roots of contemporary mobile media (MP3 Player, iPod, 
mobile phones/app music players) in a now archaic media technology. I treat the Walkman as a portable medium and as a material artefact that functions as a site of memory (see Nora 1996). When put in the hands of users, the Walkman can aid in understanding and historicizing trends towards 'mobile intimacy' within contemporary cultures of mediatization. The study of such media devices through evoking people's memories with the help of hands on historical research, combined with oral history interviews, can help build a new kind of cultural history of mediatization. This new history reveals hidden aspects of these media technologies and explains a contemporary epoch that no longer holds these past experiences and practices.

Since the introduction of the Walkman in the early 1980s in Slovenia, portable media devices have gone through many technological, cultural, and social changes. Because the perspectives of production and consumption are intertwined, many authors suggest that to understand the culture surrounding portable media technologies we must pay attention to audiences and their uses of media, which affected the ways in which technologies were invented and how they evolved (see Geraghty 2000; du Gay et al. 2013/1997). This chapter focuses on people's memories and their dealings with the Walkman, and studies past uses of the Walkman to understand Walkman users in their broader social and cultural contexts. My study is based on an investigation of the history of Walkman technologies through hands on simulations to observe how our informants (born in the 1960s and 1970s) reacted when being faced with this old or even dead media technology. Our research reveals how these users identified with the deep material structure of this media technology, or in other words, how this technical media has transmitted and processed culture (see Parikka 2012).

This research was carried out during a Media History course in 2015-2017. I am grateful to students who helped me gather hands on history participant observations, interviews, and evidence about historical uses of the Walkman. In most cases, they interviewed their own parents or their parents' friends. They reported this as a provocative and thought-provoking experience. They had little previous conception of idea how media structured everyday life in the past. They were fascinated by how much time their parents spent on outdoor activities and on socializing with their friends in face-to-face communication, and how media took a secondary place in their lives. In most cases, they reported how they were fascinated about the "innovative ways" that they parents found when using this "cumbersome and outdated technology", as they described Walkman. They called Walkman a "old big box", tending to see it as a predecessor of their iPods or MP3 Players. They argued that their parents used media in a similar way as students use media today - they hid in their rooms and escaped from the outer world with the Walkman or they walked around engaged in media practice. They argued that their parents' media world did not differ significantly from their current media world, using similar media technologies to isolate from the world and to be mobile. The principal difference lay in how little time their parents spent with the Walkman and media in comparison to their present time spent with media. 
We gathered 114 personal testimonies of female and male users of the Walkman from urban and rural areas of Slovenia. We asked these informants to search for their old Walkmans, and many found them in their basements, closets, and attics; if they were unable to find their old devices, we placed a Walkman in their hands, and throughout the interview they carried it in their hands, played with it, demonstrated, and explained how they used it in its heyday. The method of the hands on history of the Walkman helped us to observe how people used this technology, what they did with it, and how the changes in music listening habits were introduced by allowing people to carry music with them through the development of portable devices. In addition, with portable media technologies in their hands, we were also evoking their (hi)stories regarding the contexts of uses of mobile media devices.

People's reconstructed uses and memories of media when directly faced with old technologies can help us to analyse the transformations of (portable) media in history and understand the historical roots of contemporary mobile and intimate mediatized and digitalized worlds. Such a critical attitude towards the history of the Walkman as a portable media reveals that ritualized media uses have profoundly changed, and new mobile media rituals have been invented which are nevertheless historically anchored in the first uses of portable media devices such as the Walkman (see Rothenbuhler 1998).

Reflective nostalgia for past media spaces and experiences also needs to be taken into account when discussing hands on historical approaches (see Boym 2001). I observed that all our informants who were owners/users of old equipment started to build emotional and nostalgic historical narratives the moment they started to use these old portable media devices. However, this nostalgia was not restorative or collectivist, but rather individual - they cherish the memories of the good old days or of their childhood and youth. This does not signify a desire to restore the obsolete media system, but it rather shows the feelings of people who cannot identify with new transcultural and extremely privatized mobile and on-line spaces. Most of the informants reported nostalgic and pleasant feelings when they held the Walkman in their hands. As one among many cases shows:

I have to admit that the Walkman brings beautiful memories of my youth and my socializang with friends on the basketball court, where we listened to the Walkman. I miss this. I remember how in school I used the Walkman together with my friends when we met at the playground.

(Tjaž, 39 years old)

We have to take into account that precisely such nostalgic feelings have driven the informants' recollections of the usage of the Walkman.

The case of local uses of the Walkman within the hands on historical approaches in Slovenia helps to discover the development of mobile media devices in different historical settings; how these media were used, preserved, subverted, or discarded. It also investigates the technological and cultural roots of the global mobile digital 
world order through the practical uses, subversions, and meanings of the Walkman for the first users of portable media. This paper attempts to answer the question of how the media that predate today's interactive, mobile, privatized digital forms were, in their time, contested, adopted, and embedded in everyday life (see Huhtamo and Parikka 2011).

This hands on history project is very nation-specific. The research was conducted in a specific geographical area, in Slovenia, which was a part of the broader Yugoslav socialist state in the 1980s. The Walkman entered Slovenian society under a Communist political system. These socio-political and economic circumstances represent unique or unusual ways in which the Walkman was introduced to Slovenia in the 1980s. Specifically, in the socialist economic system, there was a relatively high average well-being, but there was a shortage of technical goods and Western products (Luthar 2010). Slovenian users thus experienced the Walkman in a different way from users in Western Europe and the rest of the world. For them, the Walkman represented a Western product and the promising idea of Western capitalism, which was something that Slovenian audiences longed for (Pušnik 2010). All our informants described how they obtained Walkmans in the 1980s. In most cases, there are interesting stories about the lack of these goods in the Slovenian stores and about trips to western Italy or Austria to buy these products. Almost all informants reported how there were only one or two 'outdated' types of the Walkman in Slovenian stores, which were also very expensive.

We travelled to Austria to buy the Walkman. When I saw all these Walkmans on the shelf, it was a new world that opened to me. At that time in Slovenia in Yugoslavia, you couldn't buy all these technological innovations. We were very backward in this sense. I had to convince my parents to go to Austria to buy all these new media. I didn't want to lag behind my friends and I bought a completely new Walkman in Austria.

(Katjuša, 48 years old)

Strict customs controls on the borders between the capitalist Western world and the socialist Eastern world required audiences to smuggle this media technology into Slovenia/Yugoslavia in the 1980s. As Luthar (2006) notes, these were specifically socialist surveillance techniques, which disciplined subjects through their desire of Western goods and through consumption. Longing for the West in socialist Slovenia/Yugoslavia was connected to the peculiar practice of smuggling goods through the border, and socialist individuals were very skilful in this tacit practice. Most of our informants described the smuggling of Walkmans as a normal practice of acquiring this media technology at that time.

We went to Italy to buy me a new Sony Walkman. Sony was a real brand and it represented a Mercedes among Walkmans. My mother was scared that customs officers would discover it, but I was smarter, I hid it in my pants 
because I knew they wouldn't look there. This is the story of my first Sony Walkman, but later I was a hero in the village for having a Sony Walkman.

(Peter, 42 years old)

When our informants were reintroduced to the Walkman and when holding it in their hands and playing with it, in almost all cases they recalled two general trends. The first was their excitement over the possible portability of media technology. They realized that for the first time that they were able to be mobile and to use media technology. The second was their enthusiasm about the possibility of strictly individual, personal, or even intimate usage of that media technology. These two trends were already noticed in the late 1990s: "[. . .] the Walkman was a device that both facilitated and expressed an increasing mobility and privatization of cultural experience" (du Gay et al. 2013/1997, 19-20). The Walkman boomed in the 1980s; it presented new trends of media usage in the environment of the then mainstream mass media (like TV and radio), and it started to drastically change people's lives and especially their ways of connecting with media technology. The Walkman changed the way we listened to music and how we connected with media technology and, in a way, it represented the dawn of a new age of technology.

\section{Increasing mobility: the Walkman's portability as the predecessor of present mobile media}

Westlund $(2013,6)$ argues that the present mediascape is increasingly expanded, fragmented, privatized, digital, and mobile. Like cars, mobile media technologies have become a taken-for-granted part of present society (Ling 2012). Goggin (2011, 2-5) talks about cell phones as global mobile media: all old traditional media, from TV, radio to computers, went mobile on cell phones. Goggin examines how current mobile communication is transforming media and how mobile technology is used for reinventing place or community. Some authors argue that mobile communication has become mainstream and even omnipresent with mobile phones; it certainly is the most rapidly adopted new technology in the world, which has quickly come to seem ordinary and even necessary (Katz 2008; Goggin 2011). As Sutko and de Souza e Silva (2011) argue, mobile media require us to rethink our understanding of urban sociability, particularly how we coordinate and communicate in public spaces. What is important is their ability to increase one's spatial awareness and to encourage one to meet more people in public spaces (Sutko and de Souza e Silva 2011, 815-818).

These mobile media technologies have their roots in the past media devices. The mobile phone is a descendent of the fixed telephone, but has undergone extensive technological transformations. This device now also enables the processing of communication and information through audio, video, graphics, text, and animation (Westlund 2013, 6). Wei (2008) reasons that from early mobile media devices it has been transformed into a mobile media-rich platform that enables 
the dissemination of information, entertainment, and news. Moreover, its transformation has been influenced by many media, from the Walkman to messaging services, such as the pager (Leung and Wei 1999), and convergence processes that have involved accommodating functionalities such as the camera, GPS, and music player. Although mobiles have roots in the not-so-distant past, they have become deeply embedded in contemporary social life.

Goggin $(2011,102)$ points specifically to the late 1970s and early 1980s as a significant starting point of mobile media with the appearance of the Sony Walkman. The results of our hands on history analysis also support this thesis. All the informants stressed the importance of the portability of this medium at that time when they engaged with the Walkman device. This was actually the first thing to be noticed when we placed a Walkman in their hands and asked them to describe their feelings and memories of this technology. They reported that this technology was the first one to have drastically changed their media-communication practices in comparison to other old media, communication with which was more static. In this manner, many informants compared it to their present uses of mobile phones. As this statement illustrates:

I took my Walkman with me with a special device that I attached to my trousers. What was revolutionary with the Walkman was independence, I could listen to whatever music I wanted to, and it offered me mobility. For instance, radio meant society and adaptation, but the Walkman meant independence and solitude. For me, the only problem was when I ran down the batteries when I was travelling, although I always carried spare batteries with me. First, I was afraid of using the Walkman as mobile media, because I was afraid I would damage it, but with time it became true mobile media for me.

(Uroš, 48 years old)

Or, as another informant explained: "For me, the essence of the Walkman was its portability, it was resistant to steps and body motion, more than the Discman was later, which I used more when I was lying in bed and reading" (Simona, 39 years old).

Informants told us about their feelings of freedom when using this technology: suddenly they were not bound to a specific point in space, but they could use this media technology wherever they wanted to. They also stressed the limitation of other old media, which the Walkman overcame:

What I found the most important with the Walkman in comparison to other media was that that you could carry it around with you and that you didn't need to be connected to the electric cable. I had a Sony Walkman. I liked it very much, and I liked it that I was mobile that when listening to music I could walk around. I could clean or play and jump around with the Walkman stuck to my trousers.

(Nataša, 48 years old) 
Our informants connected the Walkman not only with entertainment, but also with work. Precisely because of its portability, this medium also entered the workspace: "I grew up on the farm and with my Walkman the work there got faster for me. My mother made a small pouch for me where I put my Walkman and I tied it up with a belt" (Miha, 49 years old).

In many cases, informants compared the Walkman to the radio, although they stressed a great difference in their usage, the radio was perceived as a more community medium and a static one, while the Walkman as a more individual medium and, most importantly, as a portable medium. Moreover, when showing us how to use this technology, many of the informants argued that the problem with this technology was its batteries and that the mobility of media at that time was severely limited to a couple of hours because the batteries quickly ran down:

I carried my Walkman in the inside pocket of my jeans jacket. We used it in the way that we could carry it around outdoors. The only thing that was problematic was its batteries. For example, one had to be very careful when using the rewinding function because the batteries ran down even quicker.

(Elena, 46 years old)

I observed that there was a generation gap in the usage of the Walkman. Older generations avoided using a Walkman as they were not familiar with mobile media use:

I listened to my Walkman at the beach and at work. When I went out, I carried it in my hands. The only problem was its batteries; they were not so cheap as they are today, and they quickly ran down. It was important because you could listen to music everywhere, although not for a long time, because the batteries ran down, but still. My parents listened to the radio more often; they didn't use the Walkman because they were not used to carrying it around with them. It was something too technologically sophisticated for them, but with my sister, we constantly listened to it. You could carry and listen to the music when you were not at home, but somewhere outdoors. Later, I also used an MP3 player, but today I use my smartphone in practically the same manner.

(Vesna, 49 years old)

However, some of the informants also lamented that it was not so easy to adapt themselves to the Walkman's portability because they were used to the stationary uses of the then mainstream media. The portability of the Walkman was something so innovative for them that they needed some time to realize that this medium was a portable one. To illustrate:

At the beginning, it was not self-evident to me that you can carry music around with you. At that time, I first saw an advantage of the Walkman 
more in its ability to put headphones on and to disconnect from the world. Mostly at home, in the bed, that you listened to audiocassettes and to have your own peace. At the beginning, it was not obvious that music could come around with me. It was a super technological toy, and it was cool that I was able to listen to music in peace privately at home. Then, I slowly changed my mind, and I realized that the Walkman could come with me wherever I go, I listened to it at the beach. This was a real advantage, although it took me some time to discover how nice it was to listen to music during some boring activities. The Walkman had only one pair of headphones, and listening to it was not a social activity; it was less social, I used it more for listening to music and to disconnect. And brains off. It was a black box, Sony I think, with bass and treble buttons at the top. At that time, it seemed so little to me, but today I laugh at how big it was.

(Marko, 52 years old)

The Walkman represented a real revolution in comparison to the mainstream media of the 1980s, especially radio, television, and the conventional telephone, which were stationary media and which required sedentary usage. It suddenly brought more active, mobile uses of media since it was freed from the network and electricity cable, although it still had some disadvantages (batteries with a limited charge capacity, impracticality of carrying many audiocassettes, etc.).

\section{Privatization of media experience: intimacy with the Walkman}

Okada $(2005,43)$ explains that the dimension of personalization and privatization of media began in the late 1970s. From the mid-1980s, cordless and extension phones were commonly placed in bedrooms as the telephone found its way into
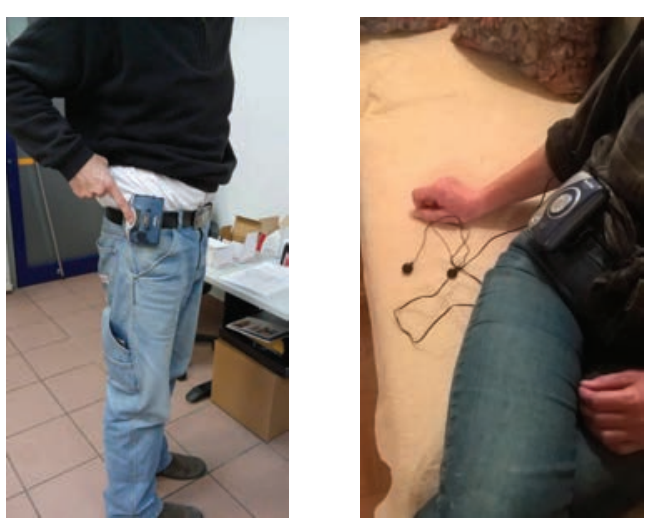

FIGURES 8.1 AND 8.2 Examples of mobile uses of the Walkman. (Photographs by Melisa Lozica and Domen Valjavec) 
the private rooms of each family member (Okada 2005, 46). The process of the personalization and privatization of media developed decisively with the popularity of the Walkman with its shift away from products used by the whole family to those used by individuals. Later, throughout the 1990s, during the adoption of mobile media, the original business and official uses of the pager were extended into individual and personal purposes. Okada (2005) describes this sequence of events as the shift from household media to individual media.

In the late 1980s, Beniger discussed the personalization of mass media by disguising the size of mass audiences, targeting messages, and contriving intimacy in content $(1987,354)$. Beniger argues that this change constitutes a transformation of traditional community into an impersonal association that we might call 'pseudo-community', which has especially been strengthened with new media-communication technology. Nowadays, new media like the mobile phone are so deeply embedded in our personal lives that some authors call these new media intimate technologies (Bell 2006). Wilska (2003) talks about the privatization of the consumption of mobilephone technology. Livingstone and Bovill $(2013,327)$ argue that privatization supports individualization and vice versa, when showing how children and youth use media technologies, which transforms more traditional communities (like family) into individual associations: "Within the home the multiplication of personally owned media may facilitate children's use of individual, privatised space, as opposed to communal family space" (Bovill and Livingstone 2001, 17).

In the modern era, we can observe a significant personalization of media and the shift to the use of media in privacy and in intimacy, enabled by the use of smartphones and personalized mobile smart applications. Spiegel (in Morley 2007, 200) transforms Williams' concept of mobile privatization (1998/1981, 284), which was brought about by television and automobility years ago. Many authors point out that modern media-communication technologies create private media bubbles in the crowd, which results in forms of ghettoization and entrapment in media bubbles, whereby media technology helps individuals to build a barrier with the outside world and, thus, enables an individual to separate his/her internal impulses from the impulses of the outer world (Boyd 2014; Morley 2007; Burchell 2015; Ling 2008; Wellman 2001; Krajina 2014; Pajnik 2015).

Hjorth and Lim (2012) presuppose that these new trends of intimacy with media already have roots in the history and in the historical forms of media:

Technologies such as mobile media re-enact earlier co-present practices and interstitials of intimacy: for example, SMS (Short Message Service) re-enacts nineteenth-century letter writing traditions [. . .] and sharing vacation photographs via Facebook are a digital analogy of the time-honored 'Wish you were here' postcard. [. . .] new forms of telepresence such as email are linked to earlier practices of intimacy such as visiting cards. In this way, the intimate co-presence enacted by mobile technologies should be viewed as part of a lineage of technologies of propinquity. 
They go even further when arguing that with the 'intimate' turn in the contemporary era of new media impacting various facets of cultural practice and politics, notions like emotion are no longer defined individually or psychologically but must be seen as an integral part of social life (Hjorth and Lim, 2012, 481). In this respect, intimacy with the Walkman in the 1980s - with headphones on users' ears resembles the modern practices of listening to an iPod or using apps on a mobile phone. In all cases, users are in an intimate relationship with media technology, remote from the outer world and locked into personal space.

With the hands on history approach, we observed two trends of personalization and privatization of the Walkman experience, when our informants reported their intimate connection with the Walkman device and their individual uses of media. First, this enabled them to move in the solitude of their personal or even intimate space, that they could disconnect from the communication with other people and from the outside world. Second, these privatized and personalized uses of the Walkman enabled them to create their own personal content; they reported that, in comparison to the radio, when listening with a Walkman they were free to listen to whatever they wanted.

The first trend of personalization and privatization of the Walkman, moving to personal, intimate space, also indicates that the users' connection with technology began to be tighter. For example: "I used my Walkman when I was alone; I locked myself with my Walkman in the solitude. It was an analogue technology, but it was reliable as long as the batteries were working" (Uroš, 48 years old). The results also show that the Walkman was a device of intrapersonal communication; with the use of the Walkman, users could escape interpersonal communication and started to communicate with themselves. Many informants reported this: "I remember whenever my parents were giving me a hard time I went out with my bike with my Walkman on my ears" (Elena, 46 years old). The Walkman entered deep into the personal and intimate space of its users, not only because it represented an escape from the real world, as our informants were claiming, but also because it replaced communication and communion with other people with communication with oneself. Hardt (2004) observes that this was already a characteristic of television media in the twentieth century, which started to attack dialogue with other people, substituting it with communion with the screen.

The Walkman also substituted communion with sound for dialogue with other people:

I disconnected from the real world with the Walkman. When I was young I shared my room with my two sisters - our apartment was crowded, and there was not a lot of privacy. The Walkman was my personal escape, if I may say so.

(Mojca, 50 years old)

Or: "For me, the Walkman was also an escape from the conversation with parents" (Tomaž, 38 years old). There were at least two advantages of the Walkman 
in comparison to the then mainstream mass media for the informants: the first was an escape to the intimate world and the second was a non-disturbance of an outer world during media activity - like listening to the Walkman: "You did not disturb your neighbourhood with your Walkman. Whenever it was something wrong or when I wanted some peace. I put on my Walkman and closed myself into my own world" (Nataša, 48 years old).

The Walkman allowed its users to escape to a private media bubble in a social space, a characteristic of contemporary media technologies:

I was obsessed with music and I wanted to listen to it on my way to the school, on my way home, on the way to my friends, everywhere and anytime. The Walkman allowed me all this, and it gave me a feeling that the outside world is not important. Immediately when I left my home, I put headphones on and I used it until I came home. Sometimes, when I felt like a real rebel, I put my headphones on during the class in the school, when the teacher had oral exams, I sat in the rear bench and I listened to my favourite songs. At home, I turned the volume up, and I couldn't hear if parents called me, and they were really nervous about that. The Walkman made music more accessible, because you could carry the device with you wherever you wanted to. This gave the music and the device a touch of freedom. You could enjoy it in private with the Walkman.

(Tine, 48 years old)

In many cases, the Walkman also represented a physical barrier from the rest of the world, with the Walkman acting as a kind of their personal room:

To me, the Walkman represented an escape to my own world. Together with my two brothers, there was no peace at my home - we were shouting, fighting. And the Walkman brought me the five minutes of peace that I needed in the day so that I could think about my future, about girls, and some other things. To carry music around with you and to listen to it whenever you wanted to was a totally new thing. The purpose of use of mobile phones is similar to that of the Walkman. As we used the Walkman to escape from reality, the same way you use your phones today.

(Matjaž, 42 years old)

Or: "I didn't have my own room, so I put my headphones on and, in the moment, I was all alone and could listen to music all by myself' (Alenka, 44 years old).

Moreover, in the case of personalization and privatization of the Walkman, I noticed a generation gap: younger informants escaped to the intimate communion with the Walkman, older ones required more communal and group uses of media:

The coming of the Walkman totally changed my habits of listening to music. I could listen to my favourite singers whenever I wanted to. We younger 
ones were separated from older ones by the Walkman. I remember that my mother and father were very angry with me and told me that I was too often alone in my room listening to music and that I should spend more time with them in the living room watching television or listening to radio.

(Barbara, 50 years old)

Or another example:

The advantage of the Walkman was that you could listen to what you wanted to. You put in an audiocassette, pushed "play" and listened to music, freed from the rest of the world; you were in your own world. However, radio was a device of the older generation, and the Walkman of the younger generation. The Walkman meant independence for me at that time, also because there often was no electricity in the evenings. The Walkman meant a great leap - MP3s and iPods are not revolutionary at all, it is only a new form of technology for listening to music. I still remember my Walkman often, and I miss those times. I still keep a collection of audiocassettes, around 500 of them.

(Dejan, 40 years old)

The Walkman isolated people from one another; instead of bringing them into contact with other users, users of technology were in contact with the Walkman. Fang $(1997,139)$ similarly argues for the TV and for the mass media culture in the twentieth century that conversations were slowly displaced from the rooms, where TV communication was going on, and the connection with the TV set was further strengthened. What started with TV was strengthened by the Walkman. In contrast, most media of the twentieth century, especially radio, are more communal media, as our informants also recognized, while the Walkman strictly sharpened these trends of isolation from others:

Radio was not so intrusive as the Walkman was. You can put it in a corner, turn down the volume and still listen to it, but at the same time drink coffee and talk with other people. Meanwhile listening to the Walkman, you cannot do that, with the Walkman you are closed with yourself into your own world. Like you were a part of some other world, into which you do not allow anybody else to enter.

(Andrej, 57 years old)

Or: "We always listened to the radio together, during lunch, for instance, but you could listen to the Walkman all by yourself at your own discretion" (Mojca, 46 years old). And:

With the Walkman, listening to music became more intimate because only you could hear the music. I mostly listened to it in my room, all alone, this 
was one to one moment - me and my Walkman/music. Radio was more community media, we listened to it together, but the Walkman was more my own media, more intimate.

(Eva, 35 years old)

The privatization and personalization of the Walkman meant also a kind of escape for its users, to escape from their everyday routines, from their obligations:

Many times, I listened to my Walkman in my room, when I needed a bit of relaxation. I shut all the windows and doors, rolled down the shutters, and I lied down on the bed in the darkness and listened to music in peace. The Walkman meant relaxation and escape from the outer world for me at the moment when I needed this. I also used it when jogging or riding a bike. I stitched it to my belt or simply on my t-shirt.

(Petra, 47 years old)

And again:

The Walkman was important because it was more a personal experience, that you could live in music. Especially if I was nervous or something bothered me, I closed myself into my room and put on the headphones. The best therapy.

(Marija, 53 years old)

The second trend of personalization is the individualization of content, processed according to personal wishes, tastes, ambitions, and interests. Informants started to prepare their own repertoire of media contents. Rando (2017) and Stock (2010) call his phenomenon the birth of the 'mixtape' with personal

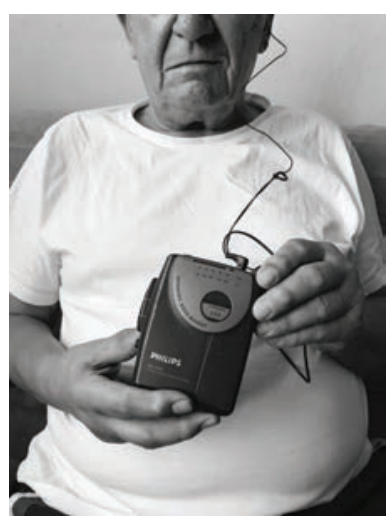

FIGURE 8.3 Privatization of the Walkman experience. (Photograph by Vita Vlašič) 
curating of users' own compilations from the radio on audiocassettes. Stock defines the mixtape thus:

The mixtape is a conglomeration of songs compiled typically by a single individual; however, some tapes are produced in tandem or groups for specific purposes. The mixtape emerged out of the improvement and affordability of recording equipment in the 1980s combined with the availability of the cassette tape released in the seventies.

This characteristic of the Walkman resembles the modern media on demand (TV or video on demand, etc.). The key new function of the Walkman that the informants remembered when playing with the Walkman in their hands was recording, which enabled this personalized content. They started to massively prepare their own repertoire of music, which individualized their usages of mass media - radio listening, for example. As one informant described:

I chose music on the radio, and then I recorded what I liked. This was a great art for me at that time. In most cases, we recorded music from the radio. The good old audiocassettes ... we were so excited about recording. I asked my parents to request some music for me on the radio for my birthday that I liked, and then I recorded it. We had to be totally silent when recording. The Walkman was a true miracle in this respect, what was the most fascinating was that you could carry it with you and listen to whatever you wanted to. When listening to the radio, you needed to adapt to others and their tastes; with the Walkman, this was different. Thus, I was in love with my Walkman.

(Tatjana, 38 years old)

The most common reason that our Walkman users made recordings of the radio was a shortage of recorded music in the 1980s in the then-socialist Slovenia/ Yugoslavia. As informants recalled, there was a "poor choice of audiocassettes in our stores": either they were expensive, or you could not buy the Western releases of popular music on cassettes at that time in Slovenia at all. There were only two ways to get Western popular music: either to travel to Austria or Italy and buy audiocassettes or to record music from the radio. According to the analysis of interviews, our informants became experts at curating compilations from the radio according to their own wishes. In this regard, Rando $(2017,65)$ calls mixtapes 'wish tapes', 'a heterotopic space' and explains different techniques for curating people's own compilations of music: "The wish image of the mixtape is also invested in reordering, restoring, and translating the commodified fragments of music back into an unalienated musical whole or totality".

Another significant reason for the mixtape was that a certain kind of male teenager wanted to compile it for courting girls. According to Stock $(2010,284)$, the 
mixtape was "a courting tool for adolescent and young adult males". Many of our male informants mentioned this trend:

I was in love with one girl from the neighbouring village, and every week when we met I recorded a new cassette with love songs in English for her because I wanted to impress her. Then we both listened to these songs together on the Walkman, each with one headphone on. I was a real stud with all these brand-new songs.

(Miro, 50 years old)

A mixtape might also be a gift, as Stock (2010) argues. A mixtape is a compilation of individual songs often presented to someone else as a gift or to denote a specific event. In this regard, the Walkman was most often compared to radio, which did not allow for such an individualized and personalized listening to music or a programme: "The Walkman was a first device that enabled you to be a master of your own music wishes, and you didn't depend on others' choices, as was the case with radio" (Žiga, 38 years old).

The mixtape was a kind of "wishful expression of the new" (Rando 2017, 11). Stock (2010), in another sense, argues that such a mixtape, which is created using other artists' songs and music for a specified purpose, is an art-based act of creativity; for him, this is a type of creative imagination. Evidence from our informants supports this theory; almost all noted that they felt free and emphasized their fantasy and imagination when they were compiling their own music together. The following informant precisely described the function of recording, which was so crucial for individualized listening with a Walkman:

I still remember that there was a show with foreign music on Mondays, and every Monday we waited with fingers on the 'record' and 'play' buttons, to record a new single. These were real events. We waited for an exact song. Many times, it happened that you recognized your favourite song too late and then you didn't have the beginning of the song, or that the speaker still spoke when the song was already on, or that he started to talk when the song was not yet over, or that there was some noise during the song. You recorded all this on your tape.

(Polona, 47 years old)

Another informant recalled: "One of my favourite activities of that time was recording audiocassettes for my Walkman. I could sit for hours listening to the radio and waiting for a certain song so that I could record it then" (Tanja, 43 years old). The testimonies of our informants reveal that they had certain rules for recording on the cassettes, which are also mentioned by Stock (2010) as important art-based rules.

Another recollection of the recording function on audiocassettes emphasized the importance of personalized content:

We mostly recorded music from radio for listening to it on the Walkman, especially the show "Top 20". If something went wrong, we rewound the 
cassette with finger or pen and recorded the new song on the tape again. It was the best that you could re-record the old song with the new one when you got bored with the old song. But then, it was a problem if the old song was longer from the new one because at the end of the new song than you could still hear the end of the old song. The Walkman represented a jump into the advanced society. It definitely changed our lives. It was a technology that certainly influenced individual's state in the society.

(Simon, 41 years old)

This example demonstrates that there were specific art-based techniques of how to prepare the mixtape and users were real craftsmen masters of this recording practice. In this regard, today's 'playlist', created by Napster, iTunes, or other computer software programmes to organize and create playlists, lacks an art of imagination that was so characteristic of mixtapes: "today, with CD burners and online servers with hundreds of thousands of songs at their fingertips, people are losing the art of making a really great mixtape" (Stock 2010, 285).

When showing us different functions of usages of the Walkman, informants specifically mentioned the rewinding/fast-forwarding function as a great advantage of this technology, because they could listen to whatever they wanted to in comparison to radio where they could not choose.

With radio, there was always a compromise what we would listen to. My word was nothing, and I couldn't listen to my favourite songs. The Walkman gave me the freedom to listen to my songs in the moment I wanted to.

(Simona, 45 years old)

It is worth mentioning that a kind of cultural nostalgia, which Rando (2017) also observed regarding the mixtape, is seen in the informants' testimonies of recording functions, which they describe as a real art and observe as unrepeatable in time.
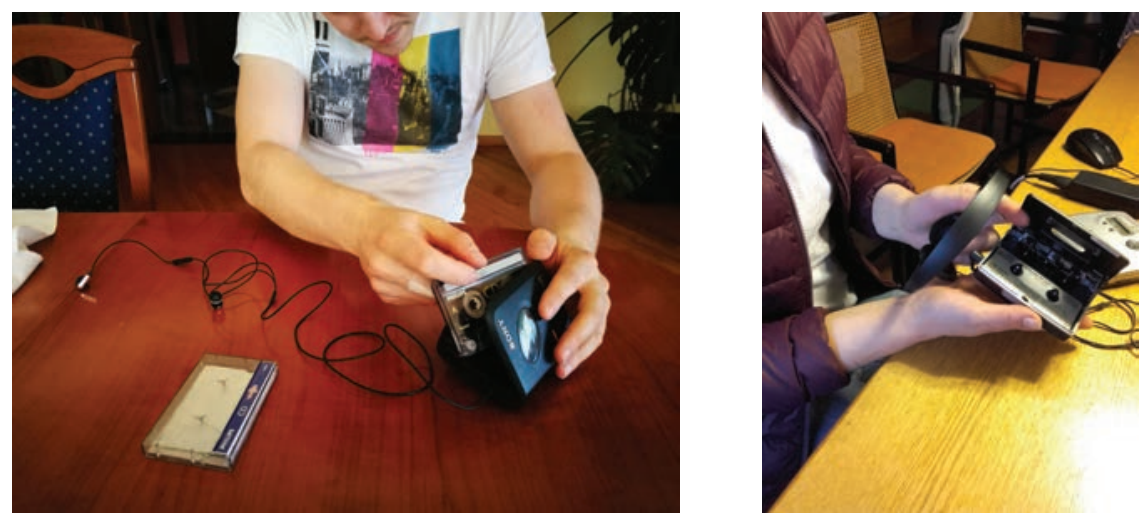

FIGURES 8.4 AND 8.5 Examples of handling the Walkman. (Photographs by Lea Plut and Ema Kranjc) 


\section{Conclusion: the Walkman and mobile intimacy}

The adoption of the Walkman in Slovenia influenced the media practices of its users and introduced them to uses which over the years have slowly become the prevailing communication practices in society. As I observed with the hands on history approach, our informants were very nostalgic about the uses of the Walkman; they were all very positive about that technology, and they mostly remembered it as a kind of freedom in comparison to the then-mainstream media. They revealed mobility, intimacy with technology, personalized content, and isolation from others. What Hjorth and Lim describe as characteristic of this century's media practices therefore has roots in the history of the Walkman:

That is, the ways in which the various forms of mobility (across technological, geographic, psychological, physical, and temporal differences) and intimacy infuse public and private spaces is spearheaded by the increasing role of personalization by mobile media to both blur and reinstate boundaries between online and offline worlds. This has allowed for multiple cartographies of space in which the geographic and physical space is overlaid with an electronic position and relational presence, which is emotional and social. This overlaying of the material-geographic and electronic-social is what can be called mobile intimacy.

It is precisely in this sense of mobile intimacy that I understand the Walkman as shaped by the social construction of its users. The process of mobile and intimate media reception became the dominant one with a new medium in the 1980s - the Walkman. A hands on historical perspective, in which users of mobile phones are faced with this old technology, can help us to understand how minor or subversive media uses evolved and transformed into mainstream media uses through time. To understand the role of the Walkman in the history of media we must understand this popular cultural device of that time as the main transformer of younger generations' trends of communication in the 1980s and 1990s. Furthermore, as Okada argues, "we must analyze how these changing media forms both grow out of and shape trends in communications. [. . .] We need an even clearer model for the relationship between media, popular cultures, and communication trends" $(2005,60)$. The growing trend of individualized and personalized use of media in present digital societies has its roots in the time of Walkman in the 1980s and our hands on history analysis proves that personalized media has played a role in culture and society long before our digital age.

\section{Notes}

1 “This gadget, originally invented and marketed by Sony in the spring of 1980 in Japan, and soon exported, has become known throughout the West, however awkward its Japanesemade English may sound" (Hosokawa 1984, 165). 
2 A starting point for my analysis are theories of the social construction of technologies technological systems (Bijker, Hughes, and Pinch 2012), which see technologies as built in a process of social construction and negotiation, which are always driven by the social interests of its participants.

\section{Bibliography}

Bell, G. (2006) The Age of the Thumb: A Cultural Reading of Mobile Technologies from Asia. Knowledge, Technology \& Policy, 19(2): 41-57.

Beniger, J. E. (1987) Personalization of Mass Media and the Growth of Pseudo-Community. Communication Research, 14(3): 352-371.

Bijker, W. E., Hughes, T. P. and Pinch, T. (2012) The Social Construction of Technological Systems: New Directions in the Sociology and History of Technology. Cambridge, MA: MIT Press.

Bovill, M. and Livingstone, S. M. (2001) Bedroom Culture and the Privatization of Media Use [online]. London: LSE Research Online. Available at: http://eprints.lse.ac.uk/ archive/00000672 (Accessed 14 September 2017)

Boyd, D. (2014) It's Complicated: The Social Lives of Networked Teens. New Haven: Yale University Press.

Boym, S. (2001) The Future of Nostalgia. New York: Basic Books.

Burchell, K. (2015) Tasking the Everyday: Where Mobile and Online Communication Take Time. Mobile Media \& Communication, 3(1): 36-52.

du Gay, P., Hall, S., Janes, L., Koed Madsen, A., Mackay, H. and Negus, K. (2013/1997) Doing Cultural Studies: The Story of the Sony Walkman. London: Sage.

Fang, I. (1997) A History of Mass Communication: Six Information Revolutions. Boston: Focal Press.

Geraghty, C. (2000) British Cinema in the Fifties: Gender, Genre and the 'New Look'. London: Routledge.

Goggin, G. (2011) Global Mobile Media. London: Routledge.

Hardt, H. (2004) Myths for the Masses: An Essay on Mass Communication. Malden and Oxford: Blackwell Publishing.

Hosokawa, S. (1984) The Walkman Effect. Popular Music, 4(1): 165-180.

Hjorth, L. and Lim, S. (2012) Mobile Intimacy in an Age of Affective Mobile Media. Feminist Media Studies, 12(4): 477-484.

Huhtamo, E. and Parikka, J. (2011) Media Archaeology: Approaches, Applications and Implications. Berkeley, CA: University of California Press.

Katz, J. E. (2008) Handbook of Mobile Communication Studies. Cambridge, MA: MIT Press.

Krajina, Z. (2014) Negotiating the Mediated City: Everyday Encounters with Public Screens. New York, London: Routledge.

Leung, L. and Wei, R. (1999) Who are the Mobile Phone Have-Nots? Influences and Consequences. New Media \& Society, 1(2): 209-226.

Ling, R. (2008) New Tech, New Ties: How Mobile Communication Is Reshaping Social Cohesion. Cambridge, MA: MIT Press.

Ling, R. (2012) Taken for Grantedness. Cambridge, MA: MIT Press.

Ling, R. and Campbell, S. (2011) Mobile Communication: Bringing Us Together and Tearing Us Apart. New Brunswick, NJ: Transaction Publishers.

Livingstone, S. M. and Bovill, M. (2013) Children and Their Changing Media Environment: A European Comparative Study. New York: Routledge.

Luthar, B. (2006) Remembering Socialism: On Desire, Consumption and Surveillance. Journal of Consumer Culture 6(2): 229-259. 
Luthar, B. (2010) Shame, Desire and Longing for the West: A Case Study of Consumption. In: B. Luthar and M. Pušnik, eds., Remembering Utopia: The Culture of Everyday Life in Socialist Yugoslavia. Washington: New Academia, 341-377.

Morley, D. (2007) Media, Modernity and Technology: The Geography of the New. London, New York: Routledge.

Nora, P. (1996) Realms of Memory: The Construction of the French Past. New York: Columbia University Press.

Okada, T. (2005) Youth Culture and the Shaping of Japanese Mobile Media: Personalization and the Keitai Internet as Multimedia. In: M. Ito, D. Okabe, M. Matsuda, eds., Personal, Portable, Pedestrian: Mobile Phones in Japanese Life. Cambridge, MA: MIT Press, 41-60.

Pajnik, M. (2015) Nano-Media and Connected Homeliness. International Journal of Communication, 19(9): 732-752.

Parikka, J. (2012) New Materialism as Media Theory: Media Natures and Dirty Matter. Communication and Critical/Cultural Studies, 9(1): 95-100.

Pušnik, M. (2010) Flirting with Television in Socialism: Proletarian Morality and the Lust for Abundance. In: B. Luthar, M. Pušnik, eds., Remembering Utopia: The Culture of Everyday Life in Socialist Yugoslavia. Washington: New Academia, 227-258.

Rando, D. P. (2017) Hope and Wish Image in Music Technology. London and New York: Palgrave Macmillan.

Rothenbuhler, E. W. (1998) Ritual Communication: From Everyday Conversation to Mediated Ceremony. Thousand Oaks: Sage.

Stock, P. V. (2010) Sociology and the Mixtape: A Metaphor of Creativity. The American Sociologisti, 41(3): 277-291.

Sutko, D. M. and de Souza e Silva, A. (2011) Location-aware Mobile Media and Urban Sociability. New Media \& Society, 13(5): 807-823.

Wei, R. (2008) Motivations for Using the Mobile Phone for Mass Communications and Entertainment. Telematics and Informatics, 25 (1): 36-46.

Wellman, B. (2001) Physical Place and Cyberplace: The Rise of Personalized Networking. International Journal of Urban and Regional Research, 25(2): 227-252.

Westlund, O. (2013) Mobile News: A Review and Model of Journalism in an Age of Mobile Media. Digital Journalism, 1(1): 6-26.

Williams, R. (1974) Television: Technology and Cultural Form, London: Routledge and Kegan Paul.

Williams, R. (1998/1981). Navadna kultura: izbrani spisi. Ljubljana: ISH Fakulteta za podiplomski humanistični študij.

Wilska, T.-A. (2003) Mobile Phone Use as Part of Young People's Consumption Styles. Journal of Consumer Policy, 26(4): 441-463. 